\title{
PROTOCOL ON THE APPLICATION OF THE CHARTER OF FUNDAMENTAL RIGHTS OF THE EUROPEAN UNION TO POLAND AND THE UNITED KINGDOM: A POLISH PERSPECTIVE
}

\begin{abstract}
Marija Zrno*
Summary: The entry into force of the Treaty of Lisbon and the Charter of Fundamental Rights was accompanied by scepticism on the part of some Member States regarding the widening of the Union's competences on the basis of the Charter. Although certain safeguards were provided within the Treaties and the Charter, the United Kingdom and Poland signed the Protocol on the application of the Charter that was often referred to as an opt-out. This paper will try to define its legal character, show the reasons that motivated the State to sign it (and discuss the justification) and give an answer to what the consequences of the Protocol will be for the protection of fundamental rights - all from the Polish perspective. Since it will be shown that the Protocol will not play a significant role in practice, the paper will also focus on other issues that arose within the 'Protocol context', particularly the question of the effectiveness of EU law within the diversity that exists among Member States.
\end{abstract}

\section{Introduction}

Fundamental rights protection within the EU has its roots in the case law of the European Court of Justice (ECJ), starting with the Stauder ${ }^{1}$ case (1969), in which fundamental rights as general principles protected by the ECJ were mentioned for the first time. In its subsequent case law, two sources for such a concept were identified - constitutional traditions common to the Member States ${ }^{2}$ and international human rights treaties to which Member States are parties, ${ }^{3}$ primarily the European Convention

\footnotetext{
LLM, University of Zagreb, Faculty of Law.

Case 29/96 Erich Stauder v City of Ulm (1969) ECR 00419.

Case 11/70 Internationale Handelsgesellschaft mbH $v$ Einfuhr (1970) ECR $01125 \S 4$.

3 The exact wording of the ECJ was '...international treaties for the protection of human rights on which the Member States have collaborated or of which they are signatories...' (§ 13).

Case 4/73 J Nold, Kohlen- und Baustoffgroßhandlung v Commission (1974) ECR 00491.

This seems to be connected to the fact that not all Members States were parties to the ECHR at that time. For example, France did not accede to the Convention until 1974 (the exact date of ratification was 3 May 1974). Although the ECJ's judgment dates from 14 May 1974 , we should bear in mind that it was formulated beforehand.
} 
for the Protection of Human Rights and Fundamental Freedoms (hereinafter: ECHR). A similar definition was later inserted in the Treaty on the European Union (art 6) and still exists within the same article, following the entry into force of the Treaty of Lisbon, with some new determinants in the area of fundamental rights protection, considering the Charter of Fundamental Rights (hereinafter: CFR) which, although a separate document, became legally binding, with the same legal value as the Treaties. ${ }^{4}$

The limits and use of the Union's competences are governed by three principles: the principle of conferral, the principle of subsidiarity, and the principle of proportionality (art $5 \mathrm{TEU}$ ). ${ }^{5}$

Since the CFR raised concern about the possibility of widening the Union's competences, additional safeguards were inserted in the Treaties. When defining the legal value of the CFR, art 6 of the TEU states that 'the provisions of the Charter shall not extend in any way the competences of the Union as defined in the Treaties' and that rights, freedoms and principles in the Charter shall be interpreted in accordance with the general provisions (Chapter VII of the Charter) and with due regard to the explanations referred to in the Charter that set out the sources of those provisions (para 1, subparas 2 and 3 ).

From art 51 (Title VII) of the Charter, it follows that the provisions of the Charter are addressed to the institutions and bodies of the EU (with due regard for the principle of subsidiarity) and to the Member States when they implement Union law. ${ }^{6}$ Similarly to the safeguards introduced

$4 \quad$ Article 6(1) TEU: The Union recognises the rights, freedoms and principles set out in the Charter of Fundamental Rights of the European Union of 7 December 2000, as adapted at Strasbourg, on 12 December 2007, which shall have the same legal value as the Treaties'.

5 According to the principle of conferral, the Union acts only within the limits of the competences conferred upon it by the Member States in the Treaties (while competences not conferred upon the Union remain with the Member States) (§ 2). The principle of subsidiarity provides that when the Union does not have exclusive competence in a certain area, that it acts 'only if and in so far as the objectives of the proposed action cannot be sufficiently achieved by the Member States ... but can rather, by reason of the scale or effects of the proposed action, be better achieved at Union level' (§ 3). The third principle requires that the Union does not exceed with its actions what is necessary for achieving the aims of the EU (§ 4).

It is also worth noting that the Treaty of Lisbon introduced the division of competences into three categories: exclusive competences of the Union (art 3 TFEU), shared competences (art 4), and competence to support, co-ordinate or supplement the actions of the Member States (art 6).

6 The same requirement of connection to EU law can be deduced from the case law of the ECJ. For example, in Wachauf (Case 5/88 Hubert Wachauf $v$ Bundesamt für Ernährung und Forstwirtschaft (1989) ECR 02609) it is stated that '...requirements of the protection of fundamental rights in the Community legal order ... are also binding on the Member States when they implement Community rules ... the Member States must, as far as possible, apply those rules in accordance with those requirements' (§ 19). It seems, however, that the requirement of the fundamental rights protection is necessarily respected also in cases in which Member States derogate from Union law (see, for example page 43 in the ERT case (Case 
in art 6 of the TEU, art 51 para 2 of the CFR provides that the Charter does not establish any new power or task, and neither does it modify the powers and tasks as defined by the Treaties (the so-called standstill clause).

However, defining the aim of the CFR (from the preamble, it can be seen that the reaffirmation of fundamental rights in six chapters of the Charter has the aim of making those rights more visible, in order to strengthen their protection, as has been found to be necessary in the light of changes in society) and the above-mentioned safeguards failed to influence the decision of some Member States to 'opt out' of the Charter by signing the Protocol on the Application of the Charter of Fundamental Rights of the European Union to Poland and the United Kingdom (the so-called British-Polish Protocol) ${ }^{7}$ or making declarations similar to it. ${ }^{8}$ Since every Member State has its own reasons for such actions, and in compliance with the aim of this work, further analysis will focus on the Polish perspective on fundamental rights protection in the EU and the Protocol itself.

Following a short overview of the political context of the signing of the Protocol, more attention will be given to its legal significance and the question as to whether the Protocol really is an opt-out of the CFR or just an interpretative instrument. In the subsequent analysis, the reasons that motivated Poland to join the Protocol will be presented through the prism of current EU law and legal standards that are binding upon Poland outside the EU framework, in order to answer the question of (un)

\footnotetext{
260/89 Elliniki Radiophonia Tiléorassi AE and Panellinia Omospondia Syllogon Prossopikou $v$ Dimotiki Etairia Pliroforissis and Sotirios Kouvelas and Nicolaos Avdellas and others (1991) ECR I-02925). Some authors distinguish the scope of application of EC law (as well as the binding force of fundamental rights protection) and the scope of implementation of Union law, emphasising the much broader scope of the former, and find that the necessary link to Community law is being progressively weakened in the jurisprudence of the ECJ. Continuous weakening of the link with Community law is found particularly in cases that concern the non-discrimination principle on grounds of nationality, such as Case 186/87 Ian William Cowan v Trésor public (1989) ECR 00195; Case C-85/96 Maria Martinez Sala v Freistaat Bayern (1998) ECR I-02691; and Case C-274/96 Criminal proceedings against Horst Otto Bickel and Ulrich Franz ECR I-07637. For more, see E Vranes, The Final Clauses of the Charter of Fundamental Rights: Stumbling Blocks for the First and Second Convention' (2003) European Integration online Papers (EIoP) Vol 7, No 7, pages 4-5 <http://eiop.or.at/ eiop/pdf/2003-007.pdf> accessed on 15 September 2010.

7 OJ C306/157.

8 Since it was too late to join the British-Polish Protocol, the Czech Republic made Declaration No 53 on the CFR, whose content is similar to the Protocol, but without the same legal value, since it is only a unilateral declaration and thus can be used only as an interpretative document. For more, see

${ }^{A}$ Wyrozumska, 'Incorporation of the Charter of Fundamental Rights into the EU Law: Status of the Charter, Scope of its Binding Force and Application, Interpretation Problems and the Polish Position' in Jan Barcz and others (eds), Fundamental Rights Protection in the EU (CH Beck, Warsaw 2009) 100-101.
} 
justified scepticism in the State's approach to the Charter (or some of its provisions). Finally, discussion will focus on the consequences that the Protocol may have on the protection of the rights of individuals. In the concluding remarks, certain problems which have proven significant within the 'Protocol context' will also be pointed out, in particular the efficiency of EU fundamental rights protection within the diversities that exist among the Member States.

\section{The signing, the content, and the legal significance of the protocol}

To begin, it might be interesting to mention that, in the mandate concerning the negotiations of the new Reform Treaty that the Polish parliament, the Sejm, granted to the Polish Government, joining the 'British Protocol' was not mentioned. Moreover, on the basis of the 'fulfilment of the Polish raison d'état' (with which the mandate is concerned), Professor M Wyrzykowski, judge of the Constitutional Tribunal of the Republic of Poland, discusses the constitutionality of such action of the Government. According to Wyrzykowski, the raison d'état consists in striving for the development of rights and freedoms and their effective protection; it is based on constitutional norms and thus cannot be undermined by any form of relativisation (political, idealistic, moral or religious), which seems to be present in the case of the Protocol. ${ }^{9}$

Although the reasons for joining the Protocol will be discussed later, a few remarks should be made before analysing its content and legal significance. Firstly, the Polish Government did not create its own protocol or even negotiate on its content, but simply joined the British version of it, and secondly, the Protocol appears to be more a political compromise than an intentional act on the part of the current Government. ${ }^{10}$ This is important for two Declarations - one on the CFR (No 61) and another concerning the Protocol (No 62), ${ }^{11}$ made by the Polish Government and which will be analysed together with the Protocol, for a better understanding of its intentional content from the Polish point of view.

\footnotetext{
9 The mandate concerned the following issues: the compromising character of the Treaty; improving the functioning of the Union, while guaranteeing Poland a strong position; weighing voices in the Council; and the accomplishment of the Polish raison d'état through its presence in the EU, M Wyrzykowski, 'Introduction: Limitations of Power and Limits of Interpretation' in Barcz (n 8) 25-28.

10 The initiative to opt out from the CFR came from the previous Government of Jaroslaw Kaczynski and his Law and Justice party ('conservatives'). The new Government ('liberals') under Prime Minister Donald Tusk decided to uphold the position of the former Government, in order to gain support in Parliament (Sejm) for the ratification of the Treaty of Lisbon. More about the political background of joining the Protocol at $<$ http://www.statewatch.org/news/2008/jan/01eu-poland.htm> accessed on 15 September 2010.

11 Both Declarations were annexed to the Final Act of the Intergovernmental Conference which adopted the Treaty of Lisbon. They are published with other annexed declarations, in OJ C 83/355.
} 


\subsection{An opt-out or an interpretative instrument?}

The Protocol is an international agreement, an amendment to the Treaty of Lisbon, and although often referred to as an opt-out, it is also considered in both academic and political circles to be an interpretative instrument. ${ }^{12}$ When we look at the Preamble of the Protocol, in which it is said that the contracting parties are desirous of 'clarifying the application of the Charter in relation to the laws and administrative action of Poland and of the United Kingdom and of its justiciability' and that 'references in this Protocol to the operation of specific provisions of the Charter are strictly without prejudice to the operation of other provisions of the Charter' (emphasis added), we can conclude that opting out is not the aim of the Protocol. It seems that the will of the Member States was to ascertain the limits of interpretation of the Charter; more precisely, the interpretation of certain provisions of the Charter to which the Protocol refers.

Article 1(1) of the Protocol seems to substantiate this conclusion:

The Charter does not extend the ability of the Court of Justice of the European Union, or any court or tribunal of Poland or of the United Kingdom, to find that the laws, regulations or administrative provisions, practices or action of Poland or of the United Kingdom are inconsistent with the fundamental rights, freedoms and principles that it reaffirms. (Emphasis added.)

The use of the words 'does not extend' can hardly justify the interpretation that the ECJ or national courts in Poland or the United Kingdom never find their laws or practices inconsistent with fundamental rights. 'Does not extend' implies that the ECJ and national courts have such competences, but these follow from current EU law, excluding the possibility of the CFR widening that competence. When compared to the above-mentioned safeguards provided by EU law (the principles of conferred competences and subsidiarity, art $6 \mathrm{TEU}$ and art $51 \mathrm{CFR})$, the question arises: what are the novelties that the Protocol introduces for the position of the contracting parties, as compared to other Member States?

\footnotetext{
12 Prof Dashwood sees it as 'part of the belt-and-braces approach of the Government', in line with the negation of the creation of new rights in the Charter or enlarging the possibility of the act being challenged on the grounds of fundamental rights, concluding that the Protocol provided 'additional, but unnecessary protection'. Jane Golding considers that the main aim is 'a certainty that all the angles are covered'; Prof Shaw defines the Protocol as 'a Declaration masquerading as a Protocol'; Martin Howe QC even questions the special position of the United Kingdom or Poland, discussing the possibility that it is simply a declaratory act of the consequences the Charter has across the whole EU; even the British Government discussed whether it was only an 'interpretative guide' that simply reaffirms the safeguards already provided within the CFR. For more on the discussion on the interpretative character of the Protocol, see the Tenth Report of the House of Lords' Committee on the European Union at

<http://www.publications.parliament.uk/pa/ld200708/1dselect/ldeucom/62/6209.htm> accessed on 15 September 2010.
} 


\subsection{Chapter IV of the CFR ('solidarity') - contradictory attitudes of the Republic of Poland}

The second paragraph of Article 1 of the Protocol states:

In particular, and for the avoidance of doubt, nothing in Title IV of the Charter creates justiciable rights applicable to Poland or the United Kingdom except in so far as Poland or the United Kingdom has provided for such rights in its national law.

At first glance, the provision confirms the 'not exclusion, but not-extension' interpretation of the meaning of the Protocol. Indeed, by saying that only those rights of Chapter IV that are recognised in Polish law will be justiciable in Poland, it merely limits a potentially more extensive application of the CFR (without completely excluding its application in that field). But before we draw any conclusions about the consequences of such limitations for the protection of the individual's fundamental rights in practice, we should look at another document produced by the Polish Government that refers to the same Chapter - Declaration No 62 concerning the Protocol:

Poland declares that, having regard to the tradition of social movement of 'Solidarity' and its significant contribution to the struggle for social and labour rights, it fully respects social and labour rights, as established by European Union law, and in particular those reaffirmed in Title IV of the Charter of Fundamental Rights of the European Union. ${ }^{13}$ (Emphasis added.)

What appears to be illogical is the striking difference between this and the explanation of the meaning of art 1(2) of the Protocol. Not only does the Declaration confirm that social and labour rights are respected in Poland in accordance with Union standards, but it also emphasises respect for those set out in the Charter (to which the Protocol's limitations refer). Despite the fact that the Declaration does not have the same legal significance as the Protocol, the fact that its content is completely contrary to that expressed in art 1(2) of the Protocol is useful in understanding that exclusion, or even limitation of the application of Chapter IV of the CFR, was not the intention of the Republic of Poland (but of the author of the Protocol's text, the United Kingdom). ${ }^{14}$

Whether it was intentional or not, and regardless of the real motives by which the Republic of Poland was guided in joining the Protocol, the fact is that certain limitations have been set and they will have a certain impact on the protection of these rights in practice.

\footnotetext{
13 OJ C 83/358.

14 Declaration No 61 on the CFR confirms that Polish reasons for an 'opt-out' were related to other fields of law. They will be analysed in the following chapters of the work.
} 


\subsection{National framework of the CFR application}

Just as the second paragraph of art 1 provides for Chapter IV of the $\mathrm{CFR}$, art 2 of the Protocol stipulates those provisions of the Charter that refer to national laws and practices, and states that they will be applied to contracting parties to the extent that the rights or principles that it contains are recognised in the law or practices of Poland or of the United Kingdom'. Reference to national laws and practices in the Charter can be found in the Preamble, where it says that 'the Union contributes to the preservation and to the development of these common values while respecting the diversity of cultures and traditions of the people of Europe as well as the national identities of the Member States'. More particularly, some articles in the Charter explicitly provide that the rights and principles to which they refer shall be guaranteed in accordance with national laws governing the exercise of those rights (the right to marry and the right to found a family (art 9), the right to conscientious objection (art $10(2)$ ), the right to education (art 14(3)) and health care (art 35) $\left.)^{15}\right)$. There are also some provisions that refer to both Community law and national laws. ${ }^{16}$ The CFR refers to national laws and practices once more in its general provisions. As the amended art 52 para 6 (compared to its 2000 version) states, 'Full account shall be taken of national laws and practices as specified in this Charter'.

We can draw two conclusions from art 2 of the Protocol, which refers to such provisions: first, for the application of those provisions it is necessary that they be confirmed in Polish law or practices, and, second, application is possible only within the scope of protection as defined by Polish law and practices (this also concerns Chapter IV of the CFR, since art 1(2) of the Protocol provides similar limitations). It may seem that the intention of the Protocol was to clarify that the Charter does not recognise any new rights, and, that in cases of referral to national laws, the scope of protection provided by a Member State is to be strictly respected. The practical implication of such a limitation is that, as far as the citizens of the contracting parties who seek protection of rights allegedly violated in situations related to EU law are concerned, they will have to prove that the (Charter) right invoked exists in their own national law and demand protection within the provided (national) framework.

However, all the above consequences are of little significance when we take into consideration the differences between the Polish and CFR

\footnotetext{
15 Arte 35 specifies that exercise of that right will be guaranteed 'under the conditions established by national laws and practices'.

16 See for example art 16 (freedom to contact a business), art 27 (workers' right to information and consultation within the undertaking), art 28 (right of collective bargaining and action), art 30 (protection in the event of unjustified dismissal), art 34 (social security and social assistance) and art 36 (access to services of general economic interest).
} 
systems of protection. We should bear in mind that, on the one hand, the CFR reaffirms the rights which can be found in different international treaties and constitutions of the Member States while, on the other hand, the Republic of Poland is a party to many international treaties concerning human rights protection (and, unlike the United Kingdom, accepts the monistic approach towards international law). Indeed, comparisons of the Polish legal system (especially constitutional provisions and those of the international treaties to which it is a party) with that introduced by the CFR show few differences. ${ }^{17}$

The application of the 'national framework' we have described takes into account only situations in which the CFR is invoked, in order to emphasise that even in such cases, the limitations imposed will not have significant consequences in practice. The application of the Union's standards outside the Charter (which seems to be even more important from the point of view of the Protocol's significance in practice) will be described later in this work.

\section{Reasons for signing the protocol - are they justified?}

\subsection{Morality issues}

Declaration No 61 on the CFR indicates the real reasons that motivated Poland to join the Protocol:

The Charter does not affect in any way the right of the Member States to legislate in the sphere of public morality, family law, as well as the protection of human dignity and respect for human physical and moral integrity. ${ }^{18}$

In other words, it was feared that, through the CFR, the EU would impose standards contrary to those represented as Polish attitudes toward questions such as abortion, euthanasia and (apparently the most frequently invoked) same-sex marriages. Such fears were expressed many times by

\footnotetext{
17 Roman Wieruszewski compared these systems by adopting standards stemming from the European Convention on Human Rights, other treaties adopted within the Council of Europe, the International Covenant on Civil and Political Rights and the International Covenant on Economic, Social and Cultural Rights as the most representative. Comparing these international standards and the Polish Constitution with the CFR, he found that they were mostly in compliance. A few exceptions concern, for example, the definition of 'family life' (important in terms of the right to privacy and family life, the right to marry and the right to found a family), where the standard is much narrower when the Polish Constitution is considered. For that and other examples, see R Wieruszewski, 'Provisions of the Charter of Fundamental Rights in the Light of the 1997 Constitution of RP and International Agreements which are Binding upon Poland' in Barcz (n 8) 114-144.
}

18 OJ C 83/358. Polish reasons for joining the Protocol will be discussed later in this text. 
'conservative' politicians ${ }^{19}$ and representatives of the Catholic Church, ${ }^{20}$ which has great influence on social and political life in Poland.

Since most attention was given to same-sex marriages, further analysis will focus on a comparison of the current situation in Poland and EU law (and international law standards) in this area, as well as on the question as to whether fears regarding the imposition of more liberal standards on Poland are justified.

\subsubsection{The question of homophobia in Poland}

Perhaps the best indicator of the question of homophobia in Poland is the research conducted by the European Union Agency for Fundamental Rights (FRA): 21 'Homophobia and Discrimination on Grounds of Sexual Orientation in the EU Member States: Part I - Legal Analysis'22 and the Resolution of the European Parliament on homophobia. ${ }^{23}$

The FRA's Report includes examples of discrimination on the grounds of sexual orientation in employment, acts of violence, expressions of hatred, and bans on demonstrations (see, for example, the judgment before the European Court of Human Rights Baczkowski and others $v$ Poland of 2007). ${ }^{24}$ In the European Parliament's Resolution, they call on the

\footnotetext{
19 K Szymański (Member of the European Parliament) sees the main aim of the Protocol as the avoidance of widening EU competences by means of ECJ case law, stating, for example, 'No one can assure us today that ... the principle of non-discrimination ... and lack of a clear definition of marriage in the Charter will not result in the future in a postulate of at least particular acknowledgment of chosen consequences of such relationships in a growing number of Member States', or 'No one is capable of guaranteeing that the principle of human dignity ... will not lead to pressures to acknowledge the right to euthanasia'. For this and other political statements, see Wyrozumska (n 8) 102-103.

20 Besides the lack of reference to God in the Preamble, as the main arguments against the Charter, they also invoke issues regarding the right to life and non-discrimination on the grounds of sexual orientation, Wyrzykowski (n 9) 33.

21 The FRA was established by Council Regulation No 168/2007 as the successor to the European Monitoring Centre on Racism and Xenophobia (EUMC). According to arts 3 and 4 of that Regulation, the FRA tasks focus on collecting and analysing data on fundamental rights protection and giving advice on its improvement, all within the scope of EU law. The Multi-annual Framework for 2007-2012 also prescribes as one of the topical areas of its work discrimination based on sex and sexual orientation (art 2(b)) OJ L 53/1; OJ L 63/14. 22 <http://www.fra.europa.eu/fraWebsite/attachments/FRA_hdgso_report_Part\%201_ en.pdf $>$ accessed on 15 September 2010.

${ }^{23}$ European Parliament resolution of 26 April 2007 on homophobia in Europe P6_ TA(2007)0167.

24 A similar report on the social situation provides information that between 2000 and 2007 the Ombudsman received 26 complaints concerning discrimination against LGBTs (ten cases qualified for further investigation). These cases raised issues of discrimination in organising public assemblies, discrimination in employment, a lack of respect for the human dignity of LGBT persons in public debates, discrimination in the course of law enforcement activities undertaken by the police as well as discrimination regarding voluntary blood donation. For more information, see
}

<http://fra.europa.eu/fraWebsite/attachments/FRA-hdgso-part2-NR_BE.pdf> accessed on 15 September 2010. 
Polish authorities to refrain from proposing or adopting legislation that would be inconsistent with the EU policy on LGBTs ${ }^{25}$ rights protection (§ 10); moreover, to condemn and take measures against declarations by public leaders inciting discrimination and hatred based on sexual orientation (§ 11); and finally, it is suggested that a delegation be sent which would gain a clear picture of the situation in Poland and initiate dialogue among the parties concerned (§ 13).

As far as 'marriage' is concerned, it is clear from Polish law that this refers only to opposite-sex couples by definition: 'Marriage, being a union of a man and a woman...' (art 18 of the Constitution of the Republic of Poland of 1997). ${ }^{26}$ Other institutions, such as registered partnership, for example, are not recognised by Polish law. Not only are same-sex couples prohibited from marrying in Poland, but examples in practice show that they are also being prevented from (or at least they run into great difficulties when) trying to contract a marriage or registered partnership in countries whose laws allow them to do so. This is no random affair, as is shown by the finding that the instruction not to provide same-sex couples with certificates confirming their unmarried status (which they are usually asked to present abroad) was sent to local governments by the Ministry of Internal Affairs and Administration, with the explanation that Polish law recognises only heterosexual marriages. ${ }^{27}$

\subsubsection{Imposing new standards in EU law?}

When speaking of imposing new standards on Poland concerning same-sex marriages, or even euthanasia and abortion, we have to ask ourselves: does the EU have such competences, and what does current EU law say about it?

Firstly, it should be repeated and pointed out that the EU does not refer to questions that are not the subject matter of the Community (eg euthanasia and abortion). The well-known case SPUC $v \operatorname{Grogan}^{28}$ can be cited as an example of the ECJ avoiding ruling on questions of high moral issues. Secondly, even when Community matters impinge upon subjects in which Member States have prerogatives, national laws and practices are respected. In the area of family law we have examples of such refe-

\footnotetext{
25 Lesbians, Gays, Bisexuals and Transsexuals.

26 English version of the Constitution at

<http://www.sejm.gov.pl/prawo/konst/angielski/kon1.htm> accessed on 15 September 2010.

${ }^{27}$ For more about this case, see A Rzepliński, 'Legal Study on Homophobia and Discrimination on Grounds of Sexual Orientation in Poland' (2008) FRALEX 19-20.

${ }_{28}$ Case C-159/90 The Society for the Protection of Unborn Children Ireland Ltd $v$ Stephen Grogan and others (1991) ECR I-04685.
} 
rence to national standards in the so-called Free Movement Directive ${ }^{29}$ and the Family Reunification Directive. ${ }^{30}$ When defining 'family members' for the purposes of its application, the first Directive refers to both spouses and partners with whom Union citizens have contracted a registered partnership, but to the latter only if the legislation of the host Member State treats registered partnerships as equivalent to marriage and only in accordance with the conditions laid down by that Member State (art 2(b)). The Family Reunification Directive, on the other hand, refers only to spouses, but provides in art 4(3) that Member States may, with respect to family reunification, decide that registered partnerships are to be treated on equal terms as marriages. ${ }^{31}$ Thirdly, even for the new competences that the Treaty of Lisbon introduced, the consent of the Member State is included in the procedure of adopting new regulations. ${ }^{32}$

As far as the CFR is concerned, it is true that it does not provide a definition of marriage, but when granting the right to marry and right to found a family in art 9, it says that they 'shall be guaranteed in accordance with the national laws governing the exercise of these rights'. Asking for a definition of marriage or, more particularly, a definition which would include only opposite-sex marriages in the Charter, does not seem realistic when we take into consideration that there are 27 Member States of the EU that regulate the issue differently and that some of them recognise same-sex marriages in their legislation (eg Spain, Belgium, Norway).

On the other hand, recent ECJ case law, especially the Maruko case ${ }^{33}$ has given rise to concern that the ECJ's activism will widen EU competences in that field. Mr Maruko entered into a life partnership and

\footnotetext{
29 Directive 2004/38/EC of the European Parliament and of the Council of 29 April 2004 on the right of citizens of the Union and their family members to move and reside freely within the territory of the Member States [2004] OJ L158.

30 Council Directive (EC) 2003/86 of 22 September 2003 on the right to family reunification [2003] OJ L251.

31 In the FRA Report (106-07), it is discussed whether such a solution violates the right to private life and the principle of non-discrimination, since it is not allowed for a durable relationship to continue by joining partners, and same-sex couples are deprived of rights that are granted to opposite-sex couples in marriage when a certain Member State does not recognise same-sex marriages.

32 Speaking of possible new regulations in the field of family law in the EU, art 81 TFEU (ex 65 TEC) on judicial co-operation in civil matters should be mentioned. In para 3 it is stated: '.. the Council, on a proposal from the Commission, may adopt a decision determining those aspects of family law with cross-border implications which may be the subject of acts adopted by the ordinary legislative procedure. The Council shall act unanimously after consulting the European Parliament. The proposal ... shall be notified to the national Parliaments. If a national Parliament makes known its opposition within six months of the date of such notification, the decision shall not be adopted. In the absence of opposition, the Council may adopt the decision'.

${ }_{33}$ Case C-267/06 Tadao Maruko v Versorgungsanstalt der deutschen Bühnen (2008) ECR I-01757.
} 
after the death of his same-sex partner, he applied for a widower's pension. He was rejected on the grounds that the regulation did not provide for such an entitlement for surviving life partners, but only spouses. The ECJ found that Directive 2000/78 in essence precludes such legislation, whereby the surviving partner does not receive the survivor's benefit granted to a surviving spouse, although, national law places same-sex couples in a situation comparable to that of spouses ( $\S 73)$. This finding would not be unusual in itself, because it is a confirmation that the EU respects national regulations regarding same-sex partnerships or similar institutions. The reason why the Maruko case became so well-known was the finding of the ECJ that:

civil status and the benefits flowing there from are matters which fall within the competence of the Member States and Community law does not detract from that competence. However, it must be recalled that in the exercise of that competence the Member States must comply with Community law and, in particular, with the provisions relating to the principle of non-discrimination (§ 59). (Emphasis added.)

This part of the judgment, which asks Member States to comply with EU law even in matters that are not within EU competences, may be interpreted as allowing the ECJ the possibility of finding such inconsistencies, thus widening the competence of the EU. However, this should not be interpreted as an imposition of standards on Member States, requiring them to recognise same-sex marriages.

The proposal given in the FRA's Legal Analysis, based on international law standards, moves in the direction of completely excluding differences in treatment between same-sex and opposite-sex couples. The idea is that Member States should recognise the institution of same-sex marriages, or something similar to it, as registered partnership or a de facto durable relationship, which would lead to extending to the partners the same benefits enjoyed by married couples. This proposal is based on the claim that when there is a certain 'package of rights or advantages' provided for married people, discrimination based on sexual orientation is necessarily present, since the rationale of deliberate choice justifies a difference in treatment between married and unmarried couples, but cannot justify such treatment when same-sex couples are not allowed to get married in certain States. ${ }^{34}$ Speaking of new tendencies within EU law, the proposal for changes in anti-discrimination law should be mentioned, especially as this also concerns discrimination on the grounds of sexual orientation.

34 Pages 55-58. 


\subsubsection{New tendencies in EU anti-discrimination}

Pursuant to art 19 TFEU (ex art 13 TEC), ${ }^{35}$ which prescribes the basis for the competences of the EU in combating discrimination, two Directives were enacted in 2000 - the Employment Equality Directive ${ }^{36}$ and the Racial Equality Directive (so-called RED). ${ }^{37}$ Among the grounds for combating discrimination in matters relating to work and employment, the first Directive also includes sexual orientation. RED (which covers only the grounds of racial or ethnic origin), on the other hand, has a much broader scope of application besides work and employment. ${ }^{38} \mathrm{Im}$ plementation of the Employment Equality Directive showed that some Member States have extended its scope of application to all (nine Member States) or some (ten Member States) fields to which RED applies, ${ }^{39}$ for example, social protection, education or access to and supply of goods and services. Since some Member States are showing a tendency to join the first group in widening the scope of the Employment Equality Directive, and since it seems unjustifiable to support the current 'hierarchy of grounds' ${ }^{40}$ there is an initiative within the EU to adopt the so-called

35 Paragraph 1: 'Without prejudice to the other provisions of the Treaties and within the limits of the powers conferred by them upon the Union, the Council, acting unanimously in accordance with a special legislative procedure and after obtaining the consent of the European Parliament, may take appropriate action to combat discrimination based on sex, racial or ethnic origin, religion or belief, disability, age or sexual orientation.'

36 Council Directive (EC) 2000/78 of 27 November 2000 establishing a general framework for equal treatment in employment and occupation OJ L303.

37 Council Directive (EC) 2000/43 of 29 June 2000 implementing the principle of equal treatment between persons irrespective of racial or ethnic origin OJ L 180.

38 Art 3(1): 'Within the limits of the powers conferred upon the Community, this Directive shall apply to all persons, as regards both the public and private sectors, including public bodies, in relation to:

(a) conditions for access to employment, to self-employment and to occupation, including selection criteria and recruitment conditions, whatever the branch of activity and at all levels of the professional hierarchy, including promotion;

(b) access to all types and to all levels of vocational guidance, vocational training, advanced vocational training and retraining, including practical work experience; (c) employment and working conditions, including dismissals and pay;

(d) membership of and involvement in an organisation of workers or employers, or any organisation whose members carry on a particular profession, including the benefits provided for by such organisations;

(e) social protection, including social security and healthcare;

(f) social advantages;

(g) education;

(h) access to and supply of goods and services which are available to the public, including housing.'

39 It is interesting to note there was a proposal in Poland on broadening the scope of the Directive to almost all fields covered by RED except access to good and services. For more, see FRA Report 25-35.

40 This term is used to show that grounds of racial or ethnic origin enjoy higher protection than others, such as sexual orientation, according to art 19 TFEU.. The practical consequence is that, for example, a same-sex couple denied a room in a hotel on these grounds cannot claim protection from the Directives, while a Roma couple can, because RED covers 'access to and supply of goods and services'. 
'Horizontal Directive', which would prohibit discrimination on the grounds of religion and belief, sexual orientation, age and disability outside the employment sphere (in other words, RED's scope of application). ${ }^{41}$

\subsubsection{ECHR standards}

While there are fears on one side (within EU law on fundamental rights) that new standards will be imposed on Poland through the CFR, the reality on the other side, within the ECHR system (binding upon Poland), concerns the same issue.

The first and best example is a recent case, Kozak $v$ Poland $^{42}$ (March 2010), which deals with discrimination on the grounds of sexual orientation. According to the facts of the case, the applicant had lived in a homosexual relationship in a flat rented by his partner, sharing expenses. He was registered as a permanent resident at the address. After the death of his partner, the applicant wanted to conclude a lease agreement in his own name, but was consequently refused and ordered to vacate the flat. Polish law requires that a person seeking succession to a tenancy must have lived with the tenant in the same household in a close relationship, such as de facto marital cohabitation. Therefore the Polish courts rejected the applicant's claim on the grounds that under Polish law, only a different-sex relationship qualified as 'de facto marital cohabitation'. The European Court of Human Rights (hereinafter: ECtHR) first stated that in principle, the protection of the family in the traditional sense ('the union of a man and a woman') was a legitimate reason which might justify differences in treatment (§ 98). Before its ruling, the ECtHR took into consideration that, in pursuance of this aim, there was a variety of measures that might be implemented by the State and that the Convention should be interpreted in the light of 'developments in society and changes in the perception of social, civil-status and relational issues, including the fact that there is not just one way or one choice in the sphere of leading and living one's family or private life'. States must also take this into account when choosing means to protect their legitimate interests (§ 98(3)). The ECtHR concluded that, in line with the finding that States have a narrow margin of appreciation in adopting measures that result in a difference based on sexual orientation, the measure adopted in this case (the exclusion of homosexual partners from succession to a tenancy) was not necessary and thus contrary to art 14 (non-discrimination) and art 8 (right to private and family life) of the Convention (§ 99).

It should be noted that the right to marry is defined in art 12 of the ECHR, which grants that right to 'men and women of marriageable age...

${ }_{41}$ Commission Legislative and Work Programme 2008 COM (2007) 640, 25-26.

42 Kozak v Poland (App no 13102/02) (2 March 2010). 
according to the national laws governing the exercise of this right'. ${ }^{43}$ Arts 12 and 8 (the right to family life) were construed as excluding same-sex relationships. ${ }^{44}$ Even in the Kozak case (which follows on from previous rulings of the ECtHR, eg Karner $v$ Austria $^{45}$ ) the ECtHR did not give a clear answer on whether same-sex couples are entitled to protection under 'family life', but relied instead on other aspects of art 8 ('private life' and 'home'). However, more recent case law (particularly, Schalk and Kopf $v$ Austria ${ }^{46}$ of June 2010) shows that changes in society are being taken into consideration, on the basis of which the ECtHR explicitly stated that the right to family life includes same-sex relationships ('a cohabiting same-sex couple living in a stable de facto partnership ${ }^{37}$ ), but still leaving to the State's discretion the decision on the scope of the right to marry ${ }^{48}$. The cases described are examples of new standards being developed on the basis of other articles and other rights than the right to marry, which is important in clarifying the distinction between the right of the State not to recognise same-sex marriages and its obligation to eliminate unjustified discrimination and not violate the other rights of individuals. This

43 Text of the ECHR in English at
$<$ http: / / www.echr.coe.int / N R / rdonlyres / D 5 C C 2 4 A 7 - D C 1 3-43 18-B 457-
5C9014916D7A/0/ENG_CONV.pdf> accessed on 15 September 2010.

44 See, for example the case $S v$ the United Kingdom, in which the European Commission of Human Rights declared the application inadmissible and stated, among other things, that 'it has already found that, despite the modern evolution of attitudes towards homosexuality, a stable homosexual relationship between two men does not fall within the scope of the right to respect for family life ensured by Article 8 (Art. 8) of the Convention' $S v$ the United Kingdom (App no 11716/85) Commission Decision of 14 May 1986 DR $47 \S 2$.

45 Karner $v$ Austria (App no 40016/98) 24 July 2003 § 40-43.

46 Schalk and Kopf v. Austria (App no 30141/04) 24 June 2010.

47 In $\S 93$ the ECtHR found that 'a rapid evolution of social attitudes towards same-sex couples has taken place in many member States. Since then a considerable number of member States have afforded legal recognition to same-sex couples ... Certain provisions of EU law also reflect a growing tendency to include same-sex couples in the notion of "family". It continued in $\S 94$ that 'In view of this evolution the Court considers it artificial to maintain the view that, in contrast to a different-sex couple, a same-sex couple cannot enjoy "family life" for the purposes of Article 8. Consequently the relationship of the applicants, a cohabiting same-sex couple living in a stable de facto partnership, falls within the notion of "family life", just as the relationship of a different-sex couple in the same situation would.' See also the case of $P B$ and JS $v$ Austria, in which the ECtHR stated the same in $\S 30$ (although, in line with changes in the legislation in question, it did not find a violation of arts 14 and 8).

$P B$ and JS $v$ Austria (App no 18984/02) 22 July 2010.

48 It is interesting to note that in the case Schalk and Kopf $v$ Austria concerning the alleged violation of art 12, the ECtHR took into consideration the right to marry as defined by the CFR and held that it would no longer consider that art 12 must in all circumstances be limited to marriage between opposite-sex couples. It added, however, that 'marriage has deep-rooted social and cultural connotations which may differ largely from one society to another. The Court reiterates that it must not rush to substitute its own judgment in place of that of the national authorities, who are best placed to assess and respond to the needs of society' 62 .

Schalk and Kopf v Austria (App no 30141/04) 24 June 2010. 
distinction is even more important within the EU legal system, in which Member States' competences and the discretion they enjoy in certain fields must be taken into account, in respect of the necessity to secure the full effectiveness of EU law. The example of the Maruko case shows that case law is developing in this direction.

The second example, the case of Tysiac $v$ Poland, ${ }^{49}$ concerns abortion and will be presented to show that, in comparison to the EU system, the ECHR system has a broader scope of application in such fields. According to the facts of the case, the applicant was a pregnant woman about whom numerous doctors concluded that she faced a serious health risk (blindness) if the pregnancy continued. She was refused a certificate which would allow her to terminate the pregnancy. After the delivery, her eyesight was badly damaged. Although Polish law legitimises abortion in certain cases (when pregnancy endangers the mother's life or health, or that of the foetus, or is the result of a criminal act) the ECtHR found that the law made the abortion provisions ineffective (criminalisation faced by doctors; inappropriate retrospective measures such as civil law tort or criminal proceedings; the absence of preventive procedures, and taking into account the time factor, the need to consider the patient's views). ${ }^{50}$ Based on these findings, the ECtHR concluded that art 8 (the right to private life) had been violated, because the State had failed in its obligation to adopt effective measures (§ 128 and 130).

When we take into consideration these two examples of developing standards within the ECHR system that is binding upon Poland, any intentions of avoiding imposing new standards within the EU by excluding or limiting the application of the CFR seem even more unreasonable.

\subsection{Social interest of the state}

Some politicians and the Polish Ombudsman have claimed that the Protocol protects Polish social interests, as otherwise employment standards would be higher. ${ }^{51}$ It is well known that low labour costs in Poland give the country a comparative advantage over other Member States. It has been claimed that social and labour rights and freedoms as prescribed in the CFR could jeopardise the Polish position in the common market. In answer to this allegation, we should take into consideration two things: first, what we have already mentioned about the contradic-

\footnotetext{
49 Tysiac $v$ Poland (App no 5410/03) 20 March 2007.

50 § 116-125.

51 In the Ombudsman's interview for the Polish newspapers and his letters to the Prime Minister, other allegations concerning the CFR were also raised: the insecurity that results from the number of general clauses and principles; the finding that the CFR is premature, unclear and ambiguous; that it disturbs the balance of power by granting judges too many rights, etc, Wyrzykowski (n 9) 31-33.
} 
tory contents of Declaration No 62 and the Protocol on Chapter IV ${ }^{52}$ and, second, that ECJ case law has developed, in the field of social and labour rights, standards which the Protocol does not exclude. But before presenting an analysis of the standards developed by case law, the provisions of the Treaties and the CFR in this field will be discussed.

\subsubsection{EU social policy}

Regarding the social policy of the EU, art 151 TFEU (ex 136 TEC) defines its objectives, which are, among others, improved living and working conditions and proper social protection. It is also stated that, in pursuance of these objectives, the Union and Member States will bear in mind fundamental social rights such as those recognised in the European Social Charter (1961) and the Community Charter of the Fundamental Social Rights of Workers (1989). Art 153 TFEU (ex 137 TEC) covers different fields in which the Union has the competence to support and complement the actions of the Member States. ${ }^{53}$ Although 'representation and collective defence of workers and employers interests' is one of those fields, para 5 of the same article says that this provision will not apply to 'pay, the right to association, the right to strike or the right to impose lock-outs'. Such exclusions are interesting from the point of view of the CFR, which recognises in art 28 the right to collective bargaining and action:

Workers and employers, or their respective organisations, have, in accordance with Community law and national laws and practices, the right to negotiate and conclude collective agreements at the appropriate levels and, in cases of conflicts of interest, to take collective action to defend their interests, including strike action.

\footnotetext{
52 See $\mathrm{n} 14$.

53 Article 153 (1): 'With a view to achieving the objectives of Article 151, the Union shall support and complement the activities of the Member States in the following fields:
}

(a) improvement in particular of the working environment to protect workers' health and safety;

(b) working conditions;

(c) social security and social protection of workers;

(d) protection of workers where their employment contract is terminated;

(e) the information and consultation of workers;

(f) representation and collective defence of the interests of workers and employers, including codetermination, subject to paragraph 5 ;

(g) conditions of employment for third-country nationals legally residing in Union territory; (h) the integration of persons excluded from the labour market, without prejudice to Article 166 ;

(i) equality between men and women with regard to labour market opportunities and treatment at

work;

(j) the combating of social exclusion;

(k) the modernisation of social protection systems without prejudice to point (c)'. 
Again, even though the Treaties and the CFR in various places provide safeguards for respecting the competences of the EU and Member States, by including strike action within the scope of this right, the Article might be interpreted as allowing for the widening of EU competences through ECJ case law. The next question is: what does the case law says on this matter?

\subsubsection{Case law}

Starting with the cases of Omega ${ }^{54}$ and Schmidberger, ${ }^{55}$ in which a certain fundamental right was in conflict with one of the market freedoms of the EU, the ECJ chose to 'strike a balance' between them. In these cases, the ECJ left it to the national courts to apply normative balancing in the cases before them. However, recent case law shows that the ECJ has taken a more active role in determining the proper balance between the right to collective action (including strikes) and market freedoms.

The Viking case $^{56}$ (see also Lava ${ }^{57}$ ) is an example in which the right to collective action was balanced with the freedom of establishment and freedom to provide services. The dispute arose when the shipping company Viking decided to reflag one of its ships, the 'Rosella', under the Estonian flag, in order to acquire cheaper labour. The Finnish Seamen's Union insisted on applying the Finnish collective agreement to those workers. Disagreement with the Viking company led to collective action and calls for support from international trade unions. The ECJ ruling started by finding that such action (with the aim of protecting jobs and conditions of employment) could be considered to fall within the objective of protecting workers, which EU social policy encompasses. However, the ECJ continued, that would not be the case in a situation in which 'the jobs or conditions of employment at issue were not jeopardised or under serious threat' $(\S 81)$. Although the ECJ added that it was for national courts to decide whether such requirements had been met in the case, and whether the measure taken of collective action went beyond what

\footnotetext{
54 The case concerns the prohibition of the operation of games that involve 'killing' human targets, thus 'human dignity' was in conflict with the 'freedom to provide services'.

Case C-36/02 Omega Spielhallen- und Automatenaufstellungs-GmbH Oberbürgermeisterin der Bundesstadt Bonn (2004) ECR I-09609.

55 The Schmidberger case concerns the conflict between the freedom of expression and freedom of movement of goods, which was the result of granting permission for a motorway in Austria to be closed in order to allow environmental demonstrations, Case C-112/00 Eugen Schmidberger, Internationale Transporte und Planzüge v Republik Österreich (2003) ECR I-05659.

56 Case C-438/05 International Transport Workers' Federation, Finnish Seamen's Union $v$ Viking Line ABP, OÜ Viking Line Eesti (2007) ECR I-10779.

57 Case C-341/05 Laval un Partneri Ltd $v$ Svenska Byggnadsarbetareförbundet and others (2007) ECR I-11767.
} 
was necessary to achieve the legitimate aim, ${ }^{58}$ the guideline provided in para 81 showed the more active and decisive role of the ECJ in 'striking a balance', especially when we take into consideration that concepts such as 'jeopardised' or 'serious threat' are hard to define or prove in practice.

Irrespective of the discussion on the impact such development in the ECJ's case law may (or may not) have on Polish 'fears' that their comparative advantage might be lost, the fact is that, outside the CFR, the social policy of the EU is defined in the Treaties, invoked in case law and balanced with other Union policies, and the standards thereby developed are binding upon Poland, no matter what consequences the Protocol may have.

\subsection{Property claims related to the Second World War}

As a result of the Second World War, German citizens were deprived of their properties, which became part of Polish territory. This has been the basis for political claims that the CFR might enable those German citizens to succeed with their claims against Polish citizens now living on those properties. ${ }^{59}$ In many ways, this 'reason' seems to lack legal reasoning. First of all, including the right to property in the $\mathrm{CFR}^{60}$ does not mean that this is a proper ground for property claims concerning expropriation and compensation. We must always bear in mind the special features of the EU system of fundamental rights protection, whose scope of application is linked to matters regulated by EU law. What seems even more insignificant are proposals to exclude the possibility of such property claims arising, by including in the CFR a 'temporal clause', which would stipulate that the CFR is not applicable to the period before its entry into force. ${ }^{61}$ In fact, this is insignificant, not just because such claims are not possible within the EU system, but also because the rule of international law is that treaties cannot have a retroactive effect (art 28 of the Vienna Convention on the Law of Treaties). ${ }^{62}$

\footnotetext{
58 § 84.

59 See, for example, what the Polish Minister of Foreign Affairs, A Fotyga, or the government official responsible for Polish-German relations, M. Muszyński, said in Wyrozumska (n 8) 110 , footnotes $2-4$.

60 Article 17(1) states: 'Everyone has the right to own, use, dispose of and bequeath his or her lawfully acquired possessions. No one may be deprived of his or her possessions, except in the public interest and in the cases and under the conditions provided for by law, subject to fair compensation being paid in good time for their loss. The use of property may be regulated by law in so far as is necessary for the general interest'.

61 See for example what $Z$ Galicki said in his Legal Opinion on the exempting Protocol and temporal caesura concerning the CFR in Wyrozumska (n 8) 110, footnote 4.

62 Article 28: 'Unless a different intention appears from the treaty or is otherwise established, its provisions do not bind a party in relation to any act or fact which took place or any situation which ceased to exist before the date of the entry into force of the treaty with respect to that party.' Full text of the Convention at <http://untreaty.un.org/ilc/texts/ instruments/english/conventions/1_1_1969.pdf> accessed on 15 September 2010.
} 


\section{Other objections to the CFR ${ }^{63}$}

If we conclude that the reasons for signing the Protocol and taking a somewhat restrictive approach toward the application of the CFR are based on extensive or even over-interpretation of the Charter, the question that logically follows is: how should the CFR be interpreted? Although much has been said about limitations to the application of the Charter, from the point of view of 'fears' which led to the signing of the Protocol, more has to be said about the scope and interpretation of rights and principles that the CFR encompasses.

\subsection{Ambiguity of the CFR - rights and principles}

The lack of a clear distinction between rights and principles in the Charter seems to be one of the most important issues regarding the application of the Charter. That this is so can be seen from the fact that para 5 of art 52 (entitled 'Scope and interpretation of rights and principles') was amended to the article's version as from the year 2000. This paragraph seems to provide guidelines for the interpretation of the mentioned distinction:

The provisions of this Charter which contain principles may be implemented by legislative and executive acts taken by institutions, bodies, offices and agencies of the Union, and by acts of Member States when they are implementing Union law, in the exercise of their respective powers. They shall be judicially cognisable only in the interpretation of such acts and in the ruling on their legality.

From this paragraph it follows that principles cannot be generally invoked in front of courts. The addressees of these principles are primarily EU institutions and Member States when exercising legislative or executive powers within EU competences. Only pursuant to acts which result from such actions by the EU and Member States can the principles be invoked in front of the ECJ or national courts, when either their interpretation or legality is in question.

Although it seems that the interpretation provided solves the problem of the distinction between rights and principles, the situation becomes less clear when we look at the contents of the CFR, which does not make clear the distinction between them. Indeed, the terms used in the Charter - 'must be respected and protected, 'the Union shall respect', 'shall be guaranteed', 'shall enjoy protection', 'Union policies shall ensu-

\footnotetext{
63 The aim of this section is to analyse some of the allegations about the Charter that have been raised in public discussions (see for example, $\mathrm{n} 47$ ), and which are important in discussing whether the 'fear' of widening EU competences on the basis of the CFR (a fear which is the basis of all the reasons for joining the Protocol) is generally the result of overinterpreting the Charter.
} 
re', etc - require legal interpretation to define their character. It may be useful to mention the distinction and interpretation that Dr Adam Bodnar suggests. ${ }^{64}$ He believes that the division of rights and freedoms according to principles is not enough, and that from the perspective of their normative character, we can divide the Charter's provisions into five groups: 1) rights and freedoms which may be directly invoked in front of courts; 2) rights and freedoms whose normative content depends upon national or Union law; 3) principles (autonomous and non-autonomous);65 4) aspirational and programmatic provisions; ${ }^{66}$ and 5) rights connected with EU citizenship.

If we try to place the rights and principles focused on in this paper within this distinction, we can see that the right to marry and the right to found a family belong to the second group, because of their reference to national laws and practices. As far as social rights are concerned, we may conclude that they belong mostly to the third group (eg social security and social assistance, art 34), but the right of collective bargaining and action, to which most attention was paid, belongs to rights, not principles (to the second group, because it refers to Union law and national laws and practices).

\subsection{Referring to rights for which the EU does not have competences}

Another basis for an extensive interpretation of the CFR is those rights and freedoms (eg freedom of thought, conscience and religion, art 10) which concern areas in which the EU has no competences. But before we draw any conclusions as to whether this may lead to the widening of EU competences, we must seek the real aim of the inclusion of such rights in the Charter.

Perhaps the best example is the one Lord Goldsmith gave regarding slaughterhouses. In his view, if the EU wanted to adopt a law concerning slaughterhouses (which is in accordance with its competence in agricultural matters), freedom of thought, conscience and religion would play a role in the way that the problem of rituals performed in different religions

\footnotetext{
${ }^{64}$ A Bodnar, The Charter of Fundamental Rights: Differentiated Legal Character of Charter's Provisions, Their Consequences for Individuals, Courts and the Legislator' in Barcz (n 8) $145-167$.

65 According to Bodnar, autonomous principles ('the EU recognises and respects') are those for which the Charter strictly determines the way they should be executed. Non-autonomous principles ('established in Union law and national law and practices'), on the other hand, are more open, leaving more room for their fulfilment with normative content, Bodnar (n 64) 157-158.

66 For example, Article 37 (Environmental protection): 'A high level of environmental protection and the improvement of the quality of the environment must be integrated into the policies of the Union and ensured in accordance with the principle of sustainable development'.
} 
should be taken into consideration. ${ }^{67}$ This example shows that 'fears' of the wider competences of the EU, for which the CFR serves as a good basis, are often the result of over-interpretation of the Charter, not taking into account the broader, legal context of EU actions which may justify provisions being included in the Charter which, at first sight, have nothing in common with the EU. This is even more important in the context of the entry into force of the Treaty of Lisbon, which widens the Union's competences in many areas. ${ }^{68}$

\subsection{Collision with other systems? - Relationship to the ECHR}

Since many rights in the Charter are also recognised in the ECHR, and taking into consideration the fact that the ECJ relies in its case law on the ECHR and the developed case law of the ECtHR, it is important to define that relationship, in order to exclude any misunderstandings that the multi-level system of fundamental (or human) rights may invoke.

Art 52 para 3 defines the relationship as follows:

Insofar as this Charter contains rights which correspond to rights guaranteed by the Convention for the Protection of Human Rights and Fundamental Freedoms, the meaning and scope of those rights shall be the same as those laid down by the said Convention. This provision shall not prevent Union law providing more extensive protection.

We can conclude that the CFR system guarantees as the minimum level of protection the level reached within the ECHR system, but it also provides a basis for the enhanced protection of those rights. This 'minimum level of protection' is a consequence of the ECtHR's rulings on the question of whether and under what conditions the ECtHR may review

67 Bodnar (n 64) 150.

68 Ingolf Pernice draws a comparison of the process in the EU with the development of fundamental rights in general, stating that the visibility of those rights and the legally binding character of the CFR are conditions for accepting new competences at the Union level. In the framework of the changes in the EU pillar system which reduce direct control and the legitimisation of such policies by national governments, the CFR plays the same role as the Magna Carta Libertatum (1215), the Virginia Bill of Rights (1776) and similar documents the moderation of political power and the constituting of governing power as trustee of the citizens, I Pernice, 'The Treaty of Lisbon and Fundamental Rights' in S Griller and J Ziller (eds), The Lisbon Treaty: EU Constitutionalism without a Constitutional Treaty? (Springer, New York and Vienna 2008) 236-238. This wording is in line with the preamble of the CFR when it says that the EU 'places the individual at the heart of its activities, by establishing the citizenship of the Union and by creating an area of freedom, security and justice'. 
EC law. ${ }^{69}$ The Bosphorus case ${ }^{70}$ is important because it introduced the 'test of equivalence' of human rights protection at Community level to the ECHR. The ECtHR stated that it was presumed the State had not departed from ECHR requirements when implementing legal obligations derived from membership in the organisation at issue, if the protection of fundamental rights (as regards both the substantive guarantees offered and the mechanisms controlling their observance) was at least equivalent to that for which the ECHR provided (§ 155). This presumption can be rebutted in the circumstances of a particular case, if 'it is considered that the protection of Convention rights was manifestly deficient' (§ 156). However, the concept of 'manifest deficiency' seems to be difficult to define in practice..$^{71}$ The Bosphorus case can be compared to the Solange II judgment of the German Federal Constitutional Tribunal (1986) which defined in a similar manner the relation between the Union's and the national system of fundamental rights protection (as long as the standards of protection at the EU level met German requirements). Within the multi-level system of fundamental rights protection, it is very important for those relationships to be defined in a way that enables their co-existence and further development. Moreover, it is necessary to safeguard the supremacy of EU law over national laws, in order to provide at least the same level of protection as national laws (constitutions) or the ECHR (on the basis of which national laws are reviewed). The wording of the CFR should be read taking into consideration the given context, and it should not be concluded that standards of protection have to be the same $\mathrm{e}^{72}$ (even when the ECJ relies on national constitutions or the ECHR).

\footnotetext{
69 According to the current situation (which will change if and when the EU accedes to the ECHR), the ECtHR reviews EC law indirectly; Member States are held responsible for all acts or omissions of their organs, regardless of whether such act or omission is a consequence of domestic law or international obligations they are obliged to comply with (including cases of transferred sovereign power to an international/supranational organisation). See, for example, $M \&$ Co $v$ Germany (App no 13258/87) 9 February 1990; Cantoni $v$ France (App no 17862/91) 22 October 1996; Matthews $v$ the United Kingdom (App no 24833/94) 18 February 1999.

70 In the Bosphorus case, the right to property of the Turkish airline charter company (Bosphorus) was allegedly violated by the Irish authorities (the aircraft was brought to Ireland for maintenance work) which acted on the basis of an EC Regulation. The question that arose was whether interference with the company's property rights could be justified (and to what extent) by necessity to comply with the Community's obligations, Bosphorus Hava Yollar Turizm ve Ticaret Anonim Şirketi v Ireland (App no 45036/98) 30 June 2005.

${ }_{71}$ See, for example, Cooperatieve Producentenorganisatie van de Nederlandse Kokkelvisserij UA v Netherlands (App no 13645/05) 20 January 2009.

72 In Cooperatieve Producentenorganisatie van de Nederlandse Kokkelvisserij UA v Netherlands, the ECtHR examined a preliminary ruling procedure before the ECJ, on the basis of an alleged violation of art 6 of the Convention (the right to a fair trial), since the applicant considered that the right had been violated as a result of the ECJ's refusal to allow them to respond to the Advocate General's Opinion. The ECtHR stated that the 'test of equivalence' also applied to procedures within international organisations that follow the State's action, but that such protection need not be identical to that provided by Article 6 of the Convention <http://www.rtdh.eu/pdf/20090120-cooperatieve_producentenorganisatie_kokkel_c_ netherlands.pdf $>20$, accessed on 15 September 2010.
} 
Emphasising the possibility of more extensive protection at the Union level is particularly important in fields such as anti-discrimination law, where the EU has more competences and thus more opportunities of widening protection on the basis of the non-discrimination principle. ${ }^{73}$ Within the ECHR system, on the other hand, the non-discrimination principle can only be invoked in connection with an alleged violation of some other right or freedom that the ECHR recognises. ${ }^{74}$

When defining the relationship between the CFR and the ECHR systems, the Explanations to the CFR should also be taken into account. ${ }^{75}$ Although we are not speaking of a source of law, the Explanations are a useful interpretative instrument. Art 52 para 7 says that courts shall give due regard to guidelines in the interpretation of the CFR that the Explanations provide. The Explanations set out articles that have the same scope and meaning as the corresponding articles of the ECHR ${ }^{76}$ and those in which the meaning is the same but the scope is wider than in the ECHR. ${ }^{77}$ As far as the right to marriage is concerned, more extensive

\footnotetext{
73 See Section 4.1.2.1.
}

74 Art 14: The enjoyment of the rights and freedoms set forth in this Convention shall be secured without discrimination on any ground such as sex, race, colour, language, religion, political or other opinion, national or social origin, association with a national minority, property, birth or other status'.

75 Text of the Explanations at <http://www.europarl.europa.eu/charter/pdf/04473 en.pdf $>$ accessed on 15 September 2010.

76 These are:

- Article 2 corresponds to art 2 ECHR

- Article 4 corresponds to art 3 ECHR

- Art 5(1) and (2) correspond to art 4 ECHR

- Art 6 corresponds to art 5 ECHR

- Art 7 corresponds to art 8 ECHR

- Art 10(1) corresponds to art 9 ECHR

- Art 11 corresponds to art 10 ECHR without prejudice to any restrictions which

Community law may impose on Member States' right to introduce the licensing arrangements referred to in the third sentence of art 10(1) ECHR

- Art 17 corresponds to art 1 of the Protocol to the ECHR

- Art 19(1) corresponds to art 4 of Protocol No 4

- Art 19(2) corresponds to art 3 ECHR as interpreted by the European Court of Human Rights

- Art 48 corresponds to arts 6(2) and (3) ECHR

- Art 49(1) (with the exception of the last sentence) and (2) correspond to art 7 ECHR.

77 These are:

- Art 9 covers the same field as Art 12 ECHR, but its scope may be extended to other forms of marriage if these are established by national legislation

-Art 12(1) corresponds to art 11 ECHR, but its scope is extended to European Union level

- Art 14(1) corresponds to art 2 of the Protocol to the ECHR, but its scope is extended to cover access to vocational and continuing training

- Art 14(3) corresponds to art 2 of the Protocol to the ECHR as regards the rights of parents

- Art 47(2) and (3) correspond to art 6(1) ECHR, but the limitation to the determination of 
protection in the CFR system is the logical consequence of the fact that Member States resolve this issue differently and that some of them recognise same-sex marriages.

However, it must be emphasised that these lists reflect the current status and do not preclude possible changes and developments in the law, legislation and the Treaties. This is important for understanding that the relationship between the EU and ECHR system of fundamental rights protection is not static and needs to be (re)considered from the point of view of changes in society and developments in legal protection. In other words, when the ECJ 'draws inspiration' from the ECHR, we should not expect 'copy-pasted' ECtHR case law. Although harmonised protection within a multi-level system is favourable, it should certainly not be an obstacle to the more enhanced protection of fundamental rights, especially when we take into consideration differences in systems. As already mentioned, in some areas the EU has more competences (eg anti-discrimination law) and in some areas the ECtHR is more competent to rule (eg the Tysiac case). Speaking of differences in systems, it is enough to take into consideration the 'common values' of the 27 Member States of the EU and the level of protection that the ECHR system (47 countries!) provides. Multi-level protection of fundamental rights is a reality and it is wrong to conclude that they collide because of differences or areas of overlap. We must bear in mind that overlapping is not a disadvantage in itself. On the contrary, it may strengthen the protection of fundamental rights if due regard is paid to changes and developments that occur in certain areas.

\section{Consequences for fundamental rights protection. (Conclusion be- fore the conclusion)}

This analysis has shown that the Protocol, considered as an interpretative instrument, will not play a significant role in the protection of the rights of individuals in practice, because the same (or similar) standards outside the CFR are already binding upon Poland. But no matter what the limitations imposed by the Protocol or what their impact in practice when the CFR is invoked, we can claim that the same protection of fundamental rights within the EU can be achieved on the basis of ge-

civil rights and obligations or criminal charges does not apply as regards Union law and its implementation

- Art 50 corresponds to art 4 of Protocol No 7 to the ECHR, but its scope is extended to European Union level between the Courts of the Member States.

- Finally, citizens of the European Union may not be considered as aliens in the scope of the application of Community law, because of the prohibition of any discrimination on grounds of nationality. The limitations provided for by art 16 ECHR as regards the rights of aliens therefore do not apply to them in this context. 
neral principles of EU law, which are binding upon Poland. Since it will be shown that the Protocol is on that basis insignificant, from the point of view of its final consequences in practice, the following sections will try to provide an insight into more general issues regarding fundamental rights protection indicated by the Protocol.

\subsection{General principles of EU law - a back-door for fundamental rights protection}

The general principles of the EU consist of two elements: the ECHR system (and other international treaties which are binding upon Member States, which can be concluded from case law, as explained at the beginning of this paper), and constitutional traditions common to Member States. Although there are many international treaties on human rights, the ECHR has the most significant role within EU fundamental rights protection. In analysing why this is so, we can isolate two main reasons: the fact that it is binding upon all 27 Member States of the EU, and the scope of its application. ${ }^{78}$ Its 'priority' among other international treaties evolved gradually through the case law of the ECJ - from the Nold ${ }^{79}$ case, in which there was no special reference to the ECHR, but to international treaties in general; Rutili, ${ }^{80}$ in which the ECJ referred directly to the ECHR; Familiapress, ${ }^{81}$ in which the ECJ referred to a judgment of the European Court of Human Rights, and others.

When speaking of constitutional traditions common to Member States, the first word that requires explanation is 'common'. What is common to the constitutional traditions of the 27 Member States? How should the ECJ rule in cases in which there are considerable differences among these traditions? After the Internationale Handelsgesellschaft case, ${ }^{82}$ in which the source of the ECJ's inspiration for fundamental rights protection was mentioned for the first time, the ECJ started to refer to 'common constitutional traditions' in its practice, in a way that some authors have described as the 'minimalist approach'. Cases like Hoechst v Commi-

\footnotetext{
78 The ECHR system includes: the Convention (protects above all political and citizen rights), 14 additional protocols and the case law of the Convention bodies. Although the possibilities of including new rights are limited, the dynamic interpretation of the Convention proves sometimes to be an effective substitute, as the cases discussed in this work confirm. For more about the scope of application and the ECHR system, see C Mik, 'Significance of the ECHR Provisions for the Protection of Fundamental Rights as General Principles of the EU Law in Barcz (n 8) 202-205.

79 Case 4/73 J. Nold, Kohlen- und Baustoffgroßhandlung v Commission (1974) ECR 00491.

80 Case 36/75 Roland Rutili v Ministre de l'intérieur (1975) ECR 01219.

81 Case C-368/95 Vereinigte Familiapress Zeitungsverlags- und vertriebs GmbH $v$ Heinrich Bauer Verlag (1997) ECR I-03689.

82 Case 11/70 Internationale Handelsgesellschaft mbH $v$ Einfuhr (1970) ECR 01125.
} 
ssion $^{83}$ or Australian Mining and Smelting Europe Ltd v Commission ${ }^{84}$ suggest that when certain rights are protected to different degrees in Member States, the ECJ looks for some 'common underlying principle' to uphold as part of EU law. ${ }^{85}$

However, when speaking of these two 'sources of inspiration' for fundamental rights protection in the EU, we must bear in mind that the ECJ does not have to accept the minimalist approach in all cases, nor provide exactly the same standard of protection as the ECHR ensures. On the contrary, on this basis the ECJ may develop autonomous standards that will play a significant role in ensuring the full effectiveness of EU law and thus enhance the protection of fundamental rights ('minimalism' in terms of both aspects may safeguard the supremacy of EU law in comparison to Member States and in order to avoid the review of EU law by the ECtHR).

For the purpose of answering the question on the relationship between the general principles of EU law and the CFR, art 6 TEU should be invoked again:

The Union recognises the rights, freedoms and principles set out in the Charter of Fundamental Rights of the European Union of 7 December 2000, as adapted at Strasbourg, on 12 December 2007, which shall have the same legal value as the Treaties $(\S 1)$;

Fundamental rights, as guaranteed by the European Convention for the Protection of Human Rights and Fundamental Freedoms and as they result from the constitutional traditions common to the Member States, shall constitute general principles of the Union's law (§ 3).

From the wording of art 6 we can conclude that, after the entry into force of the Treaty of Lisbon, there were 'two paths' of fundamental rights protection within the EU, the CFR system and the general principles of EU law, which have developed through the ECJ's case law and will continue to develop in the future. If it were not so, then separate paragraphs would not be used or, at least, the wording of the whole article would show that they are not only connected, but also equal. It is true, however, that the rights and principles in the Charter are not completely independent of the general principles of EU law (the Preamble shows that the CFR relies upon these principles ${ }^{86}$ ). Speaking of these 'two paths', it should be noted

\footnotetext{
83 Joined cases 46/87 and 227/88 Hoechst AG $v$ Commission of the European Communities (1989) ECR 02859.

84 Case 155/79 AM \& S Europe Limited $v$ Commission of the European Communities (1982) ECR 0157.

85 For more about the minimalist approach in the ECJ's case law, see J Steiner, L Woods and C Twigg-Flesner, Textbook on EC Law (OUP, Oxford 2003) 155-157.

86 In the Preamble, it is stated that the Charter reaffirms '... the rights as they result, in particular, from the constitutional traditions and international obligations common to the
} 
that they are not two different systems of fundamental rights protection, but more like a dual carriage-way, with two lanes running in the same direction, one of which allows faster movement towards the destination.

In addition, the wording in the Protocol that it is without prejudice 'to other obligations devolving upon Poland and the United Kingdom under the Treaty on European Union, the Treaty on the Functioning of the European Union, and Union law generally', confirm that no matter what the consequences the Protocol has for the application of the CFR, Poland is still obliged to respect other parts of EU law (which the general principles certainly are).

Recent ECJ judgments in the Mangold ${ }^{87}$ and Kücükdeveci cases ${ }^{88}$ on the interpretation of the non-discrimination principle on the grounds of age and Council Directive 2000/78/EC seem to substantiate this. In Kücükdeveci, the national provision on calculating the notice period for dismissal did not take into account periods of employment that the employee completed before reaching the age of 25. The Court found that it was not appropriate to the achievement of the aim (enabling employers to manage their personnel flexibly) because it applied to all employees who joined the undertaking before the age of 25 , whatever their age was at the time of dismissal. After ascertaining that the principle of non-discrimination on the grounds of age is a general principle of law (and that the Directive does not lay down but merely gives expression to the principle of equal treatment), the Court stated in $\S 51$ that:

it is for the national court ... to provide within the limits of its jurisdiction, the legal protection which individuals derive from EU law and to ensure full effectiveness of that law, disapplying if need be any provision of national legislation contrary to that principle. (Compare to $\S 77$ in Mangold.) (Emphasis added.)

In practical terms, this means that the ECJ might find some Polish legislation inconsistent with a fundamental right that forms part of the general principles of EU law, regardless of whether that right is reaffirmed in the Charter or whether there are any limitations imposed upon it by the Protocol.

On the basis of this interpretation, we may raise the issue of the ECJ giving similar guidelines to national courts in cases like Maruko, where

\footnotetext{
Member States, the Treaty on European Union, the Community Treaties, the European Convention for the Protection of Human Rights and Fundamental Freedoms, the Social Charters adopted by the Community and by the Council of Europe and the case law of the Court of Justice of the European Communities and of the European Court of Human Rights'.

87 Case C-144/04 Werner Mangold v Rüdiger Helm (2005) ECR I-0998.

88 Case C-555/07 Kücükdeveci v Swedex GmbH \& Co.KG (2010) ECR 00000.
} 
a certain issue falls within a Member State's competences. Is it possible that national courts will be asked to disapply even these national provisions, on the basis that they are contrary to the principle of non-discrimination? In answering that question, Advocate General Sharpston's Opinion in Bartsch may be useful. She explains that general principles of law do not operate in abstract. In order to review national measures on the basis of their compliance with the general principles of EU law, it is necessary that they fall within the scope of EU law, which is so in three cases: 1) the implementation of EU law (irrespective of the degree of the Member State's discretion ${ }^{89}$ ); 2) a situation in which some permitted derogation under EU law is invoked; and 3) other cases falling within the scope of EU law because of some specific substantive rule applicable to that situation. ${ }^{90}$

The question remains as to how the full effectiveness of EU law, particularly of the non-discrimination principle on the grounds of sexual orientation, should be ensured in cases that fall within a Member State's discretion ('marriage'), taking into consideration the diversity of solutions that Member States provide? How could we solve the question, for example, of a same-sex couple who get married in Belgium and because of work move to Poland, where their marriage would not be recognised?

Future case law will provide answers to such questions. Perhaps the Court will go one step further in stating that "nevertheless, Member States must comply with EU law', especially in line with given proposals that do not seek to impose the institution of same-sex marriages on Member States, but merely delimit discriminative effects by ensuring the same rights and advantages as for opposite-sex couples.

Besides developments in EU law, some final remarks should be offered in connection with the social and cultural areas that the EU encompasses, a connection which has proved significant in resolving issues based on differences among Member States.

89 For example, Mangold and Kücükdeveci were cases that concerned social and employment policy, where the Member States enjoy a broad discretion in the choice of measures for achieving these objectives. See § 38 in Kücükdeveci and § 63 in Mangold.

On the basis of analysis of Wachauf $v$ Germany (Case 5/88, Hubert Wachauf $v$ Bundesamt für Ernährung und Forstwirtschaft (1989) ECR 02609) and Bostock (Case C-2/92 The Queen $v$ Ministry of Agriculture, Fisheries and Food, ex parte Dennis Clifford Bostock (1994) ECR I-00955) some authors conclude that even when Member States are given certain discretion, the same should be exercised in accordance with fundamental rights. They found it doubtful, however, whether national authorities should recognise general principles that are not protected within their national legal systems, Steiner, Woods and Twigg-Flesner (n 85) 180.

90 Para 69 in the Advocate General's Opinion in case C-427/06 Birgit Bartsch v Bosch und Siemens Hausgeräte (BSH) Altersfürsorge GmbH (2008) ECR I-07245. 


\subsection{Cultural diversity and fundamental rights protection}

There are two co-existent theories in the area of human rights policy - universalism and cultural relativism. According to the first, human rights are a completely universal value, independent of cultural, historical or economic factors. The second implies that human rights are subject to relativisation in the context of foreign policy, meaning that different standards may be applicable to different countries, even when the same system of a certain treaty applies to them. Nevertheless, allegations can be made that although all these differences must be borne in mind, it is the duty of states to promote and protect all human rights and fundamental freedoms, regardless of their political, economic and cultural systems. ${ }^{91}$ Although these differences are more visible at the global level, the Protocol has shown that Member States are not always ready to step outside their national frameworks and standards for the purpose of broadening fundamental rights protection.

The preamble to the CFR begins: 'The peoples of Europe, in creating an ever closer union among them, are resolved to share a peaceful future based on common values'. European citizenship (Title V of the CFR reaffirms the rights of citizens) and common values require more than legal solutions in areas that are important to the functioning of the EU. The Chairman of the Committee on Human Rights in the Senate of the Republic of Poland, $Z$ Romaszewski, believes that the material and civilisation gaps and the diversity of moral values within the EU cannot be resolved on the basis of different types of regulations, but that the integration process (especially in the context of European citizenship) must include social integration by promoting certain attitudes, tolerance and examples of successful solutions, rather than by imposing them. ${ }^{92}$ The FRA is a good example within the EU of work on these issues. ${ }^{93}$

\footnotetext{
91 Such an attitude was expressed at the Conference when adopting the text of the Universal Declaration of Human Rights. For more about the mentioned theories, see A BienczykMissala, Human Rights in Polish Foreign Policy after 1989 (PISM, Warsaw 2006) 42-46.

92 The speech from the Conference on FRA can be found in The Problem of Guarantees for Fundamental Rights Protection in Europe (Center for International Relations, Warsaw 2007) 16-19.

93 Concerning discrimination on the grounds of sexual orientation see, for example, the European Union Agency for Fundamental Rights, 'Homophobia and Discrimination on Grounds of Sexual Orientation and Gender Identity in the EU Member States: Part II - The Social Situation' (2009)
}

<http://www.fra.europa.eu/fraWebsite/attachments/FRA_hdgso_report_Part\%202_ en.pdf $>$ accessed on 15 September 2010. 


\section{Conclusion}

The aim of this paper has been to give an overview of fundamental rights protection in the $\mathrm{EU}$ and to analyse the questions that the entry into force of the CFR and the Protocol on its application have raised.

As we have shown, the wording of the Protocol may be interpreted in such a way as to lead to the conclusion that the Protocol is more an interpretative instrument than an opt-out. Three important conclusions derive from this: first, as regards the provisions to which the Protocol refers, individuals in Poland may have to prove their existence in national law; second, the fact that the development of standards that would bind Poland is already a reality outside the CFR system shows that 'fears' expressed towards the CFR have been unreasonable; and third, regardless of how the Protocol is interpreted, there are always general principles of EU law that the ECJ can use as a backdoor for providing protection for individuals. So, how, finally, should the Protocol's significance be valued?

We may conclude, as Professor Jacqueline Dutheil de la Rochère did, that 'although the Protocol would probably provoke a significant amount of discussion and debate among lawyers, it might in the end produce little in the way of case law'.

However, irrespective of its slight or non-existent legal significance for the protection of fundamental rights in practice, we can say that the Protocol has contributed to the perception of the issues that the Member States' reasons for signing the Protocol indicated - the problem of the protection of fundamental rights as 'common values' on which the EU is founded, in the area of the diversity of the 27 Member States. Nevertheless, the respect given to such differences and work on promoting the development of fundamental rights protection may be considered a good way to solve the questions that have remained since the entry into force of the CFR. 